\title{
OBRAZ LUDZI STARSZYCH W PISMACH ŚWIĘTEGO AUGUSTYNA
}

Ludzie starsi wywarli nader pozytywny wpływ na życie św. Augustyna, stąd też wspomina on najpierw tych, których osobiście spotkał w życiu, a następnie tych, których poznał z lektury ksiagg świeckich i biblijnych.

1. Z obserwacji życia. Augustyn odwołuje się w swoich dziełach do różnych postaci. Przedstawia osoby znane sobie, mające szczególny status życiowy wpływający na jego koncepcję starości. Zwłaszcza w Confessiones spotykamy wyjątkowe postaci starych ludzi, jak m.in. Windycjan - znakomity lekarz, który jako prokonsul włożył na głowę Augustyna z Tagasty w roku 380 wieniec, kiedy ten wygrał w Kartaginie konkurs poetycki, zdobywając pierwszą nagrodę. Windycjan był dworskim medykiem, w swej praktyce unikał bolesnych zabiegów chirurgicznych, wyspecjalizował się w leczeniu niestrawności, ciesząc się przez to wielką popularnością. Nie był „złotoustym”, ale człowiekiem głębokiej wiedzy i wielkiego ducha, a błyszcząca w mowie inteligencja nadawała jego słowom wdzięk i siłę przekonywania. Św. Augustyn stwierdza, że przez tego starszego człowieka Bóg przychodził mu z pomocą przed zasięganiem rad u astrologów:

„Nawet tego starszego człowieka wykorzystałeś do udzielenia mi pomocy, nawet poprzez jego ręce zesłałeś mi lekarstwo. Zaprzyjaźniliśmy się i słuchałem z uwagą tego, co miał mi do powiedzenia, bo chociaż mowa jego była nieozdobna, jednak błyszcząca w niej inteligencja nadawała jego słowom i wdzięk, i ważkość"1.

Ów „mądry starzec" prawdziwie po ojcowsku ostrzegał go przed astrologią. Augustyn zauważa wszędzie obecną rękę Boga. Jest to więc przypadek starca, który otrzymuje pochwałę za inteligencje i pokorę, ponieważ opowiedział

${ }^{1}$ Confessiones IV 3, 5, NBA 1, 86, tłum. Z. Kubiak: Święty Augustyn, Wyznania, Warszawa 1987, 65. O starości u św. Augustyna zob. m.in. A. Sizoo, Augustinus de senectute, w: Ut pictura poesis, Leiden 1955, 184-188; A. Cacciari, La vecchiaia in S. Agostino, w: Senectus. La vecchiaia nell'antichità, ed. U. Mattioli, vol. 3: Ebraismo e cristianesimo, Bologna 2007, 513-539.

${ }^{2}$ Confessiones VII 6, 8, NBA 1, 188, Kubiak, s. 141. 
Augustynowi, że sam w młodości studiował astrologię, zamierzał ją uczynić nawet swoim zawodem i czerpać z niej środki utrzymania: potem jednak uznał księgi horoskopów za fałszywe i porzucił je na korzyść medycyny.

Drugą charyzmatyczną postacią był Symplicjan, ojciec duchowy i następca św. Ambrożego na stolicy biskupiej w Mediolanie, określony przez Augustyna „świętym starcem”3, do którego udał się z boskiego natchnienia, by wyjaśnił mu, w jaki sposób taki człowiek jak on, mógłby go naśladować, o czym pisze w Wyznaniach:

„Wiedziałem, że jest to dobry Twój sługa, jaśniejący Twoją łaską. Powiedziano mi też, że od wczesnej młodości był bezgranicznie Tobie oddany. A zdążył już się postarzeć. Sądziłem, że skoro tak długo kroczył po dobrej, przez ciebie wyznaczonej drodze, musi być bardzo doświadczony i bardzo wiele wiedzieć. W tym się nie myliłem"4.

Jeszcze w większym stopniu uwydatnia Augustyn postać Mariusza Wiktoryna, sławnego profesora retoryki, znanego tłumacza dzieł neoplatoników, nawróconego na chrześcijaństwo już w starszym wieku, a przez to cenionego przez niego jako bardziej wpływowego na jego własny rozwój drogi wiary:

„Stary Wiktoryn był człowiekiem niepospolicie uczonym. Znał do głębi wszystkie sztuki wyzwolone [...]. Był nauczycielem wielu znakomitych senatorów; i z wdzięczności za pracę profesorską, którą synowie tego świata uważają za ogromnie ważną, uczczono go wystawieniem jego posagu na forum w Rzymie. Aż do starości Wiktoryn był czcicielem bożków [...]. A na starość nie powstydził się zostać sługą Chrystusa Twego, dziecięciem czerpiącym życie z Twoich zdrojów; poddał kark pod twoje jarzmo, pochylił czoło przed hańbą krzyża 5 .

W galerii przykładów osób starszych nie zabrakło też osobistości niższego pułapu, jak w przypadku bardzo starej służebnicy, z którą była związana w sposób szczególny matka św. Augustyna św. Monika:

„Zawsze powtarzała, że dobre wychowanie zawdzięcza nie tyle zabiegom matki, ile troskliwości pewnej sędziwej służącej, która już jej ojca, gdy był niemowlęciem, na plecach nosiła, jak to dorastające dziewczęta zwykle noszą małe dzieci. Za to, jak też ze względu na sędziwy wiek i nienaganne obyczaje, pan i pani odnosili się do niej z respektem jako do szacownego członka tej chrześcijańskiej rodziny ${ }^{6}$.

Postać starej służebnicy, której nie znamy nawet imienia, odgrywa ważną rolę; jest osobą wymagającą i odpowiedzialną. Augustyn wysławia jej starość,

\footnotetext{
${ }^{3}$ Por. De civitate Dei X 29, NBA 5/1, 754.

${ }^{4}$ Confessiones VIII 1, NBA 1, 216, Kubiak, 162-163.

${ }^{5}$ Tamże VIII 2, 3, NBA 1, 220, Kubiak, s. 165.

${ }^{6}$ Tamże IX 8, 17, NBA 1, 272, Kubiak, s. 202-203.
} 
ograniczoną wprawdzie statusem socjalnym, ale bogatą w zasługi, podkreślając wyjątkową rolę jej wieku.

Jeszcze jedną, wyjątkową rolę zastrzegł Augustyn starcowi pod koniec traktatu De civitate Dei ${ }^{7}$, gdzie doświadczenie cudów traktuje jako argumentum fidei; opowiada tam anegdotę o biednym starcu Florencjuszu, człowieku pobożnym, lecz ubogim (homo religiosus et pauper), należącym do szeregu pokornych, którzy pokładali nadzieję jedynie w Bogu. Biskup Hippony pokazuje, jak wiara działa cuda: biedny człowiek doznaje pomocy materialnej dzięki wstawiennictwu dwudziestu męczenników, których pamięć cieszyła się wielką popularnością. Biskup, jak widać, ceni ludzi starych, których spotkał w swoim życiu; wszyscy oni przyczynili się do jego duchowego rozwoju.

2. Z historii i literatury. Reprezentantów starości bierze Augustyn nie tylko z obserwacji życia, ale także z historii i literatury. Ponowne odczytanie historii jako zbioru nielimitowanych przykładów moralnych, było modne w starożytnej historiografii, szczególnie późno antycznej. Także wieki średnie $\mathrm{z}$ tego korzystały. W tym sensie jednym z bardziej interesujących przykładów jest postać Gajusza Mariusza (156-86 prz. Chr.), wodza i polityka rzymskiego:

„A czyż nie zdaje wam się, że bogowie raczej dopomagali ludziom w zaspokajaniu pożądliwości? Czy nie odnosicie wrażenia, że wcale nie sprzyjali ich powściaganiu? Dzięki nim to Mariusz, człowiek nowy i niskiego pochodzenia, odznaczający się niezwykłym okrucieństwem, sprawca i przywódca wojen domowych, siedmiokroć został konsulem i dopiero w czasie siódmego swego konsulatu zmarł jako starzec, nie dostawszy się w ręce Sulli, który w najbliższej przyszłości miał osiągnąć zwycięstwo. Bo jeśli powiedziano by, że nie wspomogli go w tym wszystkim, równałoby się mającemu ważne znaczenie przyznaniu ze strony pogan, że człowieka może nawet bez łaskawości bogów spotkać owa wielka szczęśliwość doczesna, którą wyznawcy ich nazbyt silnie miłują, i że ludzie, tak jak Mariusz, mogą mieć pod dostatkiem zdrowia i sił, zasobów i zaszczytów, godności i długowieczności oraz korzystać z tych dobrodziejstw mimo rozgniewania bogów (diis iratis) ${ }^{8}$.

Augustyn przytacza to, dyskutując z teodyceą pogańską, a w szczególności z rolą i waga pobożności religijnej. Mariusza, niegodziwca i krwiożercę, zawsze nagradzanego losem i sukcesem, przeciwstawia doświadczanemu cierpieniem Regulusowi stawianemu za wzór rzymskiego męstwa i miłości ojczyzny (267 prz. Chr. po raz pierwszy był konsulem):

„Z drugiej strony mogą ludzie, tak jak Regulus, cierpieć udręki związane z pojmaniem przez nieprzyjaciół, z niewolą, niedostatkiem, pozbawieniem

${ }^{7}$ Por. De civitate Dei XXII 8, 10, NBA 5/3, 336, thum. W. Kornatowski: Święty Augustyn, O Państwie Bożym, II, Warszawa 1977, 570.

${ }^{8}$ Tamże II 23, 1, NBA 5/1, 140, 142, Kornatowski I 163-164. 
snu i bólem oraz umrzeć pośród tych cierpień mimo życzliwości bogów (diis amicis)" ".

Augustyn zastosował tutaj ciekawą z punktu widzenia stylu antytezę: Mariusz cieszy się szczęśliwością „mimo zagniewania bogów(diis iratis)”, a Regulus cierpi nieszczęścia „mimo życzliwości bogów (diis amicis)" ${ }^{\prime 10}$. Nieco dalej biskup Hippony kontynuował:

„Przypuśćmy znów, że bogowie mają w sprawach doczesnych moc wyświadczania dobrodziejstw lub wyrządzania szkód; dlaczego więc wspierali w tej dziedzinie bardzo złego człowieka, Mariusza, a opuścili bardzo szlachetnego Regulusa? Czyż przez to samo nie dają nam się poznać jako całkiem niesprawiedliwi i najwyższej mierze przewrotni? A jeśliby sądził ktoś, że dlatego właśnie trzeba się ich lękać i czcić, to jakże by się mylił! Bo przecież okazuje się, że Regulus czcił ich nie mniej, aniżeli Mariusz" ${ }^{11}$.

Autor posługując się właściwym porównaniem, zestawieniem, prawdziwą

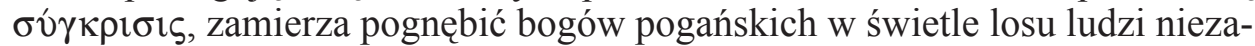
leżnie od ich stanowiska religijnego: często nagradzają złych, a dobrych karzą. Swój pogląd umacnia jeszcze, podkreślając, że bogowie nie interweniując uczestniczyli w upadku cywilizacji rzymskiej.

Spośród innych starożytnych osobistości Augustyn przytacza przykład z epoki jemu nie tylko pod względem czasowym bliższej, ale także moralnej, mianowicie cesarza Konstantyna Wielkiego:

„Panował Konstantyn długo, dzierżył cały świat rzymski i bronił go jako jedyny August. W kierowanych i toczonych przez się wojnach odnosił wspaniałe zwycięstwa. W poskramianiu tyranów cieszył się powodzeniem we wszystkich okolicznościach. Zmożony chorobą i starościa, zmarł w podeszłym wieku, przekazując władzę synom"12.

Po sukcesach militarnych i cywilnych przychodzi i u niego choroba i starość, inaczej jednak niż u wielu jego poprzedników. Przedstawia ponadto cesarza Konstantyna jako obrońcę wiary (defensor fidei): „o nic demonów nie błagającego, lecz samemu prawdziwemu Bogu cześć oddającego"13. Interpretacja tak zbudowana ma za zadanie zwalczanie idololatrii. W nagrodę już na tej ziemi otrzymał długie życie i kontynuację w potomkach, upodabniając się w ten sposób do patriarchów i sprawiedliwych w historii Izraela.

\footnotetext{
${ }^{9}$ Tamże II 23, 1, NBA 5/1, 142, Kornatowski I 164.

${ }^{10} \mathrm{O}$ Regulusie zob. też tamże I 15 i 24; III 18, 1; V 18, 2.

${ }^{11}$ Tamże II 23, 1, NBA 5/1, 142, Kornatowski I 164.

${ }^{12}$ Tamże V 25, NBA 5/1, 394, Kornatowski I 300.

${ }^{13}$ Tamże V 25, NBA 5/1, 394: „Constantinum imperatorem non supplicantem daemonibus, sed ipsum verum Deum colentem...”, Kornatowski I 301.
} 
Biskup Hippony w liście do Macedoniusza, zastanawiając się m. in. nad tym, kto jest naszym bliźnim, którego mamy kochać, aby miłować Boga, przytacza również na temat starości tekst literacki:

„Stąd i poeta komiczny (jak blask prawdy nie brakuje wspaniałym umysłom) w scenie, w której przedstawił rozmowę jednego starca z drugim wyraża się: «czy tak wiele wolnego czasu twoje sprawy pozostawiają ci, że się zajmujesz cudzymi sprawami, które cię nie obchodzą»? Drugi mu odpowiedział: «Jestem człowiekiem i nie uważam za obce niczego, co ludzkie»"14.

Augustyn przytacza, jak widać, dwa wersy z komedii Heautontimoroumenos (Samodręczyciel) Terencjusza (185-159), autora przez siebie umiłowanego ${ }^{15}$, choć, ściśle mówiąc, jest to wypowiedź Menedema z tejże komedii: „Chremes, tantumne ab re tua est oti tibi, aliena ut cures ea, quae nihil ad te adtinet?". (Chremesie, czy już nie masz nic zupełnie do roboty, skoro wtykasz nos w cudze sprawy?). Tę piękną sentencją replikuje Chremes: „Homo sum, humani nil a me alienum puto" (Człowiekiem jestem i nic, co ludzkie nie jest mi obce) ${ }^{16}$.

W kontekście palliaty te dwie osobistości reprezentują dwa różne typy senes, którzy mają odmienne spojrzenie na rzeczywistość. Wyraźnie jest podkreślona wymiana uderzeń między dwoma starcami. Topos jest antropologiczny, więcej tolerancyjny, obecność przekazów wiarygodnych także w kontekście kłamliwym, co Augustyn podsumował następująco:

„Wszystkie teatry, jak mówią, pełne głupich i niewykształconych widzów, oklaskiwały powyższe zdanie. Tak oczywiście społeczność ludzkich dusz, z natury dotyczy uczuć wszystkich, że każdy z widzów uważał siebie za bliźniego pierwszego lepszego człowieka" ${ }^{17}$.

Humaniści renesansowi uczynili z tej sentencji główne hasło epoki odrodzenia.

3. Typologie biblijne. Bardzo ważny zbiór różnych obrazów znajduje się w Biblii, co w sposób naturalny odnosi się także do starości. Temat ten pojawia się już na pierwszych stronach Księgi Rodzaju, na którą Biskup Hippony powołuje się często w swoich dziełach, zwłaszcza, kiedy wspomina wiek protoplastów:

„Wtedy bowiem ciało nie będzie nie tylko takie, jakie jest teraz, nawet przy najlepszym zdrowiu, lecz i takie, jakie przed grzechem mieli pierwsi ludzie, którzy - choć nie byliby umarli, jeśliby nie zgrzeszyli - używali jednak pokarmów, jako ludzie mający jeszcze nie duchowe, ale wyposażone w dusze, ziemskie ciała. Ciała te wprawdzie nie starzałyby się z wiekiem, iżby nieuniknienie dojść do śmierci (stan ten z cudownego zrządzenia Bożej łaski był dziełem

\footnotetext{
${ }^{14}$ Augustinus, Epistola 155, 14, NBA 22, 576, przekład własny.

${ }^{15}$ Por. H. Hagendahl, Augustine and the Latin Classics, t. 2, Goeteborg 1967, 378-380.

${ }^{16}$ Terentius, Heautontimorumenos I 1, 75-77.

${ }^{17}$ Augustinus, Epistola 155, 14, NBA 22, 576, przekład własny.
} 
drzewa żywota, które wraz z drzewem zakazanym rosło pośrodku raju), lecz pierwsi ludzie jedli też inne pokarmy prócz owoców z drzewa zakazanego"18.

Dopiero po grzechu pierworodnym pierwsi rodzice, którzy nie posiadali jeszcze ciała duchowego, ale ciało ożywione, mające duszę, byli przedmiotem starzenia się, które dla Augustyna jest integralną częścią kary. W raju bowiem człowiek:

„miał jedzenie, by zaspokoić głód, picie, by gasić pragnienie, i drzewo żywota, aby czuć się bezpiecznym przed starością" ${ }^{19}$.

W XV rozdziale De civitate Dei czyni Augustyn dużą dygresję chronologiczną i chronograficzną o długości życia patriarchów przed potopem ${ }^{20}$, zwłaszcza Noego. Inny znów profil mają wspomnienia o Sarze i Abrahamie: Sara w starszym wieku została matką. Augustyn analizuje zmianę ich imion: Sara (- pani moja) na Sarra (- moc), Abram (- wybitny ojciec) na Abraham (- Ojciec wielu narodów). Otrzymali oni dobrodziejstwo płodności, chociaż wcześniej ze względu na bezpłodność Sary i podeszłe lata Abrahama nie mogli już mieć potomstwa. Dwie żony Abrahama były sędziwe, nie tylko metaforycznie ${ }^{21}$. O starości Izaaka wspomina w swych pismach więcej razy: „Izaak się starzeje, a w związku z tym jego oczy tracą zdolność widzenia"22. Był ślepy z powodu oczu, nie umysłu, którym mógł dostrzegać światło Boże:

„Światłość [...], którą dostrzegał Izaak, o oczach cielesnych już obciążonych i zaćmionych starością, kiedy synów błogosławił nie rozpoznając ich, lecz błogosławiąc zasłużył na to, żeby ich właściwie rozpoznać"23.

Wyjaśniając w homilii alegorycznie perykopę biblijną, Augustyn przyrównuje kondycję starczą Izaaka do starości Starego Testamentu: „Starość Izaaka oznacza dawność Starego Testamentu"24. Stary ślepy Izaak chciał pobłogosławić swego starszego syna, ponieważ Stary Testament zawiera obietnice skierowane do pierwszego wybranego ludu - Żydów ${ }^{25}$.

Jeszcze bardziej uwydatniony jest przez Augustyna problem starości na przykładzie starca Symeona (Łk 2, 25-34), „człowieka sprawiedliwego i bojącego się Boga" (Łk 2, 25), który profetycznie wyrażał się o małym Jezusie. Biskup Hippony mówi o nim przy różnych okazjach zaliczając go do świętych starców, podobnie jak Jezusa do dzieci: „Macie więc, dzieci, Dziecię Jezus;

\footnotetext{
${ }^{18}$ De civitate Dei XIII 20, NBA 5/2, 258, Kornatowski II 107; zob. też tamże XIII 23, 1.

${ }^{19}$ Tamże XIV 26, NBA 5/2, 357, Kornatowski II 160.

${ }^{20}$ Por. tamże XV 14, NBA 5/2, 411, Kornatowski II 185-187.

${ }^{21}$ Por. tamże XVI 28, NBA 5/2, 525, Kornatowski II 250-251.

${ }^{22}$ Tamże XVI 37, NBA 5/2, 539, Kornatowski II 260.

${ }^{23}$ Confessiones X 34, NBA 1, 344, Kubiak, s. 256.

${ }^{24}$ Sermo 4, 11, NBA 29, 40: „Senectus Isaac vetustatem significat Veteris Testamenti”.

${ }^{25}$ Por. tamże.
} 
święci starcy, starego Symeona"26; często też wymienia go łącznie z Anną prorokinią, „bardzo podeszłą w latach, która od swego panieństwa siedem lat żyła z mężem, a potem pozostała wdową. Liczyła już osiemdziesiąty czwarty rok życia"(Łk 2, 36-37). Biskup wyjaśnia:

„Albowiem nie bez Ducha Świętego prorocy przepowiadali, co się w przyszłości stanie, a także starzec Symeon i wdowa Anna w Duchu Świętym poznali Pana jako dziecię"27.

W rzeczywistości można zauważyć, że Łukasz nie podaje, iż Symeon był podobnie jak Anna starcem. Augustyn łączy tu bardziej dwie kategorie ludzi słabych i z marginesu społecznego, przeciwstawia starość Symeona dziecięctwu Jezusa.

Podsumowując można stwierdzić, że Doktor Kościoła z wielkim szacunkiem i dozą życzliwości odnosił się do ludzi starszych i z serdeczną wdzięcznością ich wspominał. Nie brak też wszakże pewnych uwag krytycznych w kontekście historii i literatury przedchrześcijańskiej.

\section{DE SENIBUS IN SANCTI AUGUSTINI SCRIPTIS}

\section{(Argumentum)}

Disputatiuncula ex tribus partibus constat. Pars prima de senibus, quibus Augustinus occucurrit et deinde cognovit, narrat. Qui sunt: Vindicianus - medicus excellens, sapiens et humilis; Symplicianus - senex sanctus; Victorinus - artis orandi professor; tutelaris vetus famula nomine vacans, atque Florentius - homo religiosus et pauper. Qui omnes bono exemplo fuerunt Augustino. Pars altera de senibus, quos Augustinus in litteris antiquis cognovit, dicit. Gaium Marium Regulo opponit, Mario malo res fuerunt secundae, Regulus nobilis aequo animo dolorem tulit. Constantinus Magnus pro bonis actis iam in terra vita longa prosperatus est, duo senes in opere Terentii Heautontimorumenos Menedemus et Chremes exprimunt diversos patres. Pars tertia exempla biblica ostendit. Primi parentes optima valetudine morituri non essent, nisi peccassent, Abraham et Sarra virtutem ad emissionem seminis acceperunt, Senectus Isaac vetustatem Veteris Testamenti significat, Simeon senex et Anna vidua in Spiritu Sancto Dominum infantem cognoverunt.

26 Sermo 370, 4, NBA 34, 486: „Habetis ergo, pueri, puerum Jesum; sancti senes, senem Simeonem"; zob. też Contra litteras Petiliani II 72, 162, NBA 15/2, 182.

${ }^{27}$ In Joannis Evangelium tractatus 52, 8, NBA 24, 1036, thum. W. Szołdrski, PSP 15/2, 68. 
